\title{
Preliminary assessment of deptropine dihydrogen citrate in chronic airways obstruction
}

\author{
W. J. H. LECKIE AND N. W. HORNE \\ From the City Hospital, Edinburgh
}

The synthesis and the chemical properties of the compound 3-(10,11-dihydro-5H-dibenzo[a,d]cyclohepten-5-yloxy)-tropane citrate ${ }^{1}$ and a number of its congeners have been described by van der Stelt, Harms, and Nauta (1961). Funcke, de Jonge, Tersteege, Mulder, Harms, and Nauta (1962) outlined the diverse pharmacological properties of deptropine and made particular note of its effect on broncho-constriction induced by histamine and serotonin asthma in guinea-pigs. These authors also observed that deptropine had an antihistaminic effect on the isolated guinea-pig intestine 80 times more potent than diphenhydramine hydrochloride and a cholinolytic action on the same preparation about three times more active than atropine sulphate.

A similar compound, thiazinanium, with anticholinergic, antihistaminic, and antiserotonin properties, was found to be effective parenterally in reversible airways obstruction (Booy-Noord, Orie, ten Cate, Sloots, and Bolt, 1957 ; Van Geuns and Scherrer, 1955) although oral administration was surprisingly ineffective. Scherrer (1962) and Schmidt (1962) have described the clinical usefulness of the parenteral administration of deptropine in asthma and bronchitis. The former author compared the effect after three hours of the intramuscular administration of 2 or $3 \mathrm{mg}$. deptropine with $1 \%$ isoprenaline by aerosol and $0.25 \mathrm{~g}$. aminophylline by intravenous injection, and found its action in increasing timed forced expiration to be three times as powerful as isoprenaline and six times as powerful as this dose of aminophylline. None of the published reports has objective proof that the drug is effective when administered orally. Scherrer (1962), on rather limited experience, doubted the efficacy of oral therapy. McNicol and Bruyns (1964) found active deptropine to have no significant advantage over placebo therapy in 22 patients suffering from chronic bronchitis, and it produced no sympto-

1Deptropine dihydrogen citrate, Brontina matic improvement despite a small but significant decrease in sputum volume. Recent reports of the General Practitioner Research Group (General Practitioner Clinical Trials, 1964), using largely subjective methods of assessment, also suggest that deptropine had no advantage over placebo in the prophylaxis of bronchitis, but that it was as effective as chlorpheniramine in the treatment of hay fever. Voorhorst (1962) thought that the drug was useful in atrophic vasomotor rhinitis and hay fever and also as an adjuvant to corticosteroids in the treatment of asthma. Nevertheless, Quarles van Ufford and Bruens (1962) were able to show that, of 12 patients suffering from 'asthmatic bronchitis', 11 described benefit from the active preparation whereas only one preferred the placebo. Schmidt (1962) estimated the maximum respiratory minute volume in 15 of 26 patients before and after two to six weeks' oral treatment with deptropine and found an average increase of $56 \%$. This author also referred to the possible efficacy of the drug when combined with prednisolone.

In chronic bronchitis, significant reversal of airways obstruction is depressingly rare using any of the oral sympathomimetic drugs at present available. It seemed therefore most important to evaluate in some detail the effect of this compound, with its unusual pharmacological properties and promising preliminary reports, on patients suffering from bronchitis as well as on predominantly asthmatic subjects. In view of the suggestion that deptropine acted as an adjuvant to the corticosteroid therapy of asthma, patients achieving less than maximum benefit from corticosteroid treatment, as judged clinically and by ventilatory function tests, were also investigated. These patients are often severely disabled by their asthma and receive only marginal benefit from prednisolone. Significant further relief of airways obstruction would represent an important therapeutic advance.

Two groups of patients were therefore investigated: 
Group I: Patients suffering from airways obstruction due predominantly to (1) chronic bronchitis (sub-group A) and (2) chronic asthma (sub-group B) and not receiving corticosteroids.

Group II : Patients receiving long-term corticosteroids for chronic asthma or asthmatic bronchitis but obtaining less than maximal improvement on an established routine of corticosteroid therapy.

\section{METHODS}

In group I, 20 patients were studied, of whom 13 were in sub-group A and seven in sub-group B. One of the patients in sub-group $A$ had to be withdrawn during the course of the investigation because of a respiratory infection. Two of the seven patients in sub-group B were also withdrawn, one because of increasingly severe asthma and the other because of a respiratory infection. Seventeen patients therefore completed the investigation. Eight of the patients were investigated as in-patients and the remainder, including the three patients withdrawn, attended daily as out-patients.

The investigation was carried out over a period of two weeks. During the first week deptropine was administered in a dose of $1 \mathrm{mg}$. at $8 \mathrm{a} . \mathrm{m}$. and at 8 p.m., and during the second week a placebo tablet of identical appearance was taken in the same dose routine. The order of treatment was randomized and unknown to the patient, the physician, or the technician recording ventilatory function.

For the in-patients, the 24-hour sputum volume was estimated and a daily recording of the one-second forced expiratory volume (F.E.V.1.0) and forced vital capacity (F.V.C.) was made between 10 and $10.30 \mathrm{a}$.m. A Gaensler spirometer was used to obtain these values, and the highest of three separate estimations was accepted. For the out-patients, the volume of sputum expectorated between waking and 9 a.m. each morning was recorded, and the daily F.E.V.1.0 was $\stackrel{\overrightarrow{\bar{s}}}{\rightarrow}$ estimated (omitting Sundays) also at the same time of day. Bacteriological examination of the sputum was carried out at the beginning, in the middle, and at the $\frac{\bar{N}}{\sigma}$ end of the investigation, and its appearance was $\stackrel{\mathbb{Q}}{\varrho}$ recorded throughout. Many of the patients were already taking tetracycline, and, in fact, significant ${ }^{\infty}$ pathogens were only isolated from two of the out- $\vec{O}$ patients, both of whom had mucoid sputum. Two of $\overrightarrow{-}$ the in-patients expectorated purulent sputum during $\vec{\omega}$ the investigation, but this cleared rapidly with antibiotic therapy and was not thought to be of signifi- $x$ cance in assessing the results. All patients were askedî about side-effects at the end of their investigation. In nine patients reversibility of airways obstruction $\dot{\omega}$ produced by parenteral deptropine $(2 \mathrm{mg}$. intra- $\overrightarrow{\vec{V}}$ muscularly) and by adrenaline $(0.5 \mathrm{ml} .1: 1,000$ O solution subcutaneously) was measured by F.E.V.1.0 estimations immediately before and 15 minutes and $\vec{c}$ four hours after administration of the drugs. The main clinical features of the whole group are $\vec{\circ}$ described in Table I.

In group II, 12 patients were studied over a period of four months. Three failed to complete the investi- $\square$ gation: one was withdrawn because of genuine sideeffects of deptropine; one because the patient considered that deterioration was due to the tablets at a time when she was, in fact, receiving placebo ; and $\frac{\mathrm{O}}{\bar{Q}}$ the third patient was admitted to hospital because of $\mathbb{Q}$ an unrelated disorder in the third month of the $\overrightarrow{\overrightarrow{0}}$ investigation.

Treatment with deptropine, $1 \mathrm{mg}$. at 8 a.m. and at 8 p.m., and placebo tablets in the same routine was randomized in four four-weekly periods, each patient receiving two periods of active and two periods of placebo therapy. The nature of the treatment was unknown to the patient, the physician, or the tech- $x$ nician recording the F.E.V.1.0 and sputum volume. $\frac{0}{3}$ F.E.V.1.0 was recorded before treatment and fortnightly thereafter during the investigation. Sputum 0

T AB L E I

CLINICAL FEATURES IN GROUP I

\begin{tabular}{|c|c|c|c|c|c|c|c|c|}
\hline $\begin{array}{l}\text { Case } \\
\text { No. }\end{array}$ & Age & $\underset{(\mathrm{ml} .)^{1}}{\text { F.E.V }}$ & $\begin{array}{l}\text { F.V.C. } \\
(\mathrm{ml} .)^{1}\end{array}$ & $\begin{array}{l}\text { Eosinophils } \\
\text { c.mm. }\end{array}$ & Asthma & Bronchitis & $\begin{array}{l}\text { Sub-group } \\
(\text { see text) }\end{array}$ & $\begin{array}{c}\text { Duration of } \\
\text { Symptoms (years) }\end{array}$ \\
\hline $\begin{array}{r}1 \\
2 \\
3 \\
4 \\
5 \\
6 \\
7 \\
8 \\
9 \\
10 \\
11 \\
12 \\
13 \\
14 \\
15 \\
16 \\
17 \\
18 \\
19 \\
20\end{array}$ & $\begin{array}{l}59 \\
46 \\
56 \\
17 \\
57 \\
71 \\
41 \\
59 \\
66 \\
72 \\
36 \\
75 \\
66 \\
56 \\
15 \\
45 \\
58 \\
66 \\
54 \\
62\end{array}$ & $\begin{array}{r}1,100 \\
920 \\
750 \\
2,320 \\
790 \\
1,150 \\
2,500 \\
1,150 \\
1,030 \\
800 \\
1,600 \\
1,025 \\
740 \\
1,900 \\
2,200 \\
1,350 \\
1,690 \\
2,600 \\
750 \\
850\end{array}$ & $\begin{array}{l}3,800 \\
1,850 \\
2,700 \\
3,100 \\
2,550 \\
2,400 \\
4,500 \\
2,650 \\
2,000 \\
2,650 \\
4,200 \\
2,550 \\
1,800 \\
4,800 \\
4,150 \\
3,600 \\
3,200 \\
5,100 \\
1,800 \\
3,000\end{array}$ & $\begin{array}{r}300 \\
\overline{170} \\
450 \\
400 \\
650 \\
0 \\
370 \\
500 \\
0 \\
0 \\
450 \\
400 \\
0 \\
-0 \\
0 \\
170\end{array}$ & $\begin{array}{c}+ \\
++ \\
++ \\
+++ \\
+ \\
+ \\
++ \\
+ \\
+ \\
++ \\
+ \\
++ \\
+ \\
++ \\
+++ \\
+ \\
+ \\
++ \\
+ \\
+\end{array}$ & $\begin{array}{c}+++ \\
++ \\
+ \\
+++ \\
+++ \\
+++ \\
++ \\
+++ \\
++ \\
++ \\
++ \\
+++ \\
+++ \\
+++ \\
+++\end{array}$ & $\begin{array}{l}\text { B } \\
\mathbf{B} \\
\mathbf{A} \\
\mathbf{A} \\
\mathbf{B} \\
\mathbf{B} \\
\mathbf{A} \\
\mathbf{B} \\
\mathbf{B} \\
\mathbf{A} \\
\mathbf{B} \\
\mathbf{B} \\
\mathbf{B} \\
\mathbf{A} \\
\mathbf{A} \\
\mathbf{B} \\
\mathbf{B} \\
\mathbf{A} \\
\mathbf{B} \\
\mathbf{B}\end{array}$ & $\begin{array}{c}15 \\
8 \\
40 \\
15 \\
20 \\
45 \\
2 \\
15 \\
45 \\
17 \\
25 \\
3 \\
55 \\
20 \\
14 \\
35 \\
25 \\
0 \cdot 2 \\
30 \\
18\end{array}$ \\
\hline
\end{tabular}

${ }^{1}$ Highest values for F.E.V.1.0 and F.V.C. obtained at any time other than during investigation. 
T A B LE II

CLINICAL FEATURES IN GROUP II

\begin{tabular}{|c|c|c|c|c|c|c|c|c|}
\hline \multirow{2}{*}{$\begin{array}{l}\text { Case } \\
\text { No. }\end{array}$} & \multirow[b]{2}{*}{ Age } & \multicolumn{3}{|c|}{ Prednisolone } & \multicolumn{2}{|c|}{ Highest Pre-treatment } & \multirow{2}{*}{$\begin{array}{c}\text { Eosino- } \\
\text { phils/ } \\
\text { c.mm. }\end{array}$} & \multirow[b]{2}{*}{ History } \\
\hline & & $\begin{array}{c}\text { Dose } \\
\text { (mg./day) }\end{array}$ & Regime & $\begin{array}{l}\text { Duration } \\
\text { (years) }\end{array}$ & $\underset{(\mathrm{ml} .)}{\text { F.E. }}$ & $\underset{(\mathrm{ml} .)}{\text { F.V. }}$ & & \\
\hline $\begin{array}{l}1 \\
2 \\
3\end{array}$ & $\begin{array}{l}27 \\
41 \\
58\end{array}$ & $\begin{array}{l}15 \\
20 \\
20\end{array}$ & $\begin{array}{l}2 / 4 \\
3 / 7 \\
3 / 7\end{array}$ & $\begin{array}{l}1 \cdot 5 \\
1 \cdot 3 \\
0.8\end{array}$ & $\begin{array}{l}2,610 \\
1,720 \\
1,350\end{array}$ & $\begin{array}{l}3,700 \\
3,750 \\
2,220\end{array}$ & $\begin{array}{l}380 \\
390 \\
200\end{array}$ & $\begin{array}{l}\text { Asthma with marked allergic rhinitis } 13 \text { yrs. } \\
\text { Asthma with bronchitic episodes since infancy } \\
\text { Asthma with prominent bronchitic features } 20 \mathrm{yrs} \text {. Mild } \\
\text { anxiety state }\end{array}$ \\
\hline $\begin{array}{l}4 \\
5 \\
6 \\
7 \\
8 \\
9\end{array}$ & $\begin{array}{l}29 \\
56 \\
65 \\
53 \\
70 \\
23\end{array}$ & $\begin{array}{l}17 \cdot 5 \\
10 \\
15 \\
10 \\
20 \\
10\end{array}$ & $\begin{array}{c}2 / 4 \\
2: 4 \\
2 / 4 \\
\text { Daily } \\
3 / 7 \\
2 / 4\end{array}$ & $\begin{array}{l}1 \cdot 4 \\
3 \cdot 1 \\
2 \cdot 6 \\
1 \cdot 7 \\
0 \cdot 6 \\
2 \cdot 0\end{array}$ & $\begin{array}{r}3,900 \\
2,000 \\
1,310 \\
2,300 \\
950 \\
870\end{array}$ & $\begin{array}{l}5,200 \\
3,000 \\
2,800 \\
4,100 \\
2,320 \\
2,950\end{array}$ & $\begin{array}{r}450 \\
100 \\
230 \\
50 \\
412\end{array}$ & $\begin{array}{l}\text { Asthma with occasional bronchitic episodes } 3 \text { yrs. } \\
\text { Asthma with bronchitic episodes } 15 \text { yrs. } \\
\text { Asthma with occasional bronchitic episodes } 16 \text { yrs. } \\
\text { Bronchitis } 8 \text { yrs.; asthma and bronchitis } 2 \text { yrs. } \\
\text { Asthma with bronchitic episodes } 20 \text { yrs. } \\
\text { Severe asthma since infancy; very poor work record due to } \\
\text { disablement prior to start of prednisolone therapy; } \\
\text { 'pigeon-chest' deformity }\end{array}$ \\
\hline 10 & $\begin{array}{l}61 \\
71\end{array}$ & $\begin{array}{l}12 \cdot 5 \\
12 \cdot 5\end{array}$ & $\underset{1 / 2}{\text { Daily }}$ & $\begin{array}{l}5 \cdot 1 \\
1 \cdot 1\end{array}$ & $\begin{array}{l}1,210 \\
2,050\end{array}$ & $\begin{array}{l}2,100 \\
4,050\end{array}$ & $\overline{180}$ & $\begin{array}{l}\text { Asthma ; no history of allergy or bronchitis } 20 \text { yrs. } \\
\text { Increasing asthma associated with bronchitis and agitated } \\
\text { depressive illness } 7 \text { yrs. }\end{array}$ \\
\hline 12 & 24 & 15 & Daily & 0.7 & 1,270 & 2,900 & 1,700 & $\begin{array}{l}\text { Severe asthma since age } 4 \text { with bronchitic exacerbations; } \\
\text { hypersensitive to aspergillin but no imp-ovement following } \\
\text { hyposensitization; 'pigeon-chest' deformity }\end{array}$ \\
\hline
\end{tabular}

Regime: $1 / 2=$ alternate days 'on' and 'off' prednisolone. $2,4=$ alternate two days 'on' and 'off' prednisolone. $3 / 7=$ three consecutive days 'on' and four days 'off' prednisolone.

volume and character were recorded weekly, the sputum measured being that expectorated between waking and 9 a.m. Sputum was examined bacteriologically monthly. In four patients, tetracycline was taken continuously throughout the investigation, and these patients remained free of respiratory infection. Only two of the remaining five patients developed infections during the course of the investigation. One had three episodes of bronchitis with cough productive of purulent sputum, but these were controlled rapidly with tetracycline. The other patient had one mild infective exacerbation which was also rapidly controlled by tetracycline. No allowance has been made for these incidents as they occurred during months of active treatment and would tend therefore to influence the results only in favour of the placebo. The patients also kept a record sheet, noting daily the number of times per day they used an inhaler and whether they had a respiratory infection. They also recorded weekly whether their chest condition had been good, indifferent, or bad, and were asked to note any possible side-effects of treatment. The relevant clinical features of these patients are summarized in Table II.

\section{RESULTS}

GROUP I The results of oral therapy in this group are shown in Table III.

Ventilatory function There was no significant difference between placebo and active therapy when the average F.E.V..$_{1.0}$ values for the whole group were compared. Using the average of the F.E.V..$_{1.0}$ recordings during the placebo week as standard, nine of the 17 patients showed an improvement when taking the active preparation, which averaged $10 \%$ of the standard (range $1.3 \%$ to $22 \%$ ). However, seven showed a lower value with the active drug than with the placebo, the reduction also averaging $10 \%$ of the standard (range $1 \%$ to $26 \%$ ). There was no difference between placebo and active therapy in one patient. When the eight in-patients were considered alone, substantially the same results were obtained, and the results were no better when the predominantly asthmatic subjects in sub-group B were evaluated separately.

Sputum volume The sputum volume of the outpatients showed an average reduction of $28 \%$ in four (average volume $18 \mathrm{ml}$.) and an average increase of $74 \%$ in four (average volume $4.5 \mathrm{ml}$.). In the in-patients there was an average reduction in sputum volume in six (average volume $27 \mathrm{ml}$.), and in two patients the average daily volume rose, one from 13 to $19 \mathrm{ml}$. and the other from 2 to 3 $\mathrm{ml}$.

Inhaler usage Only six of the out-patients regularly used an inhaler, and in these patients the inhaler was used 71 times when they were receiving the active preparation and 42 times when they were receiving the placebo.

Subjective preference Four patients felt worse and one felt better when receiving deptropine. One felt much improved on the placebo. The others were unable to express a preference.

Side-effects Seven patients noticed marked dryness of the mouth when having deptropine, and of 
T ABLE III

RESULTS IN GROUP I

\begin{tabular}{|c|c|c|c|c|c|c|c|c|c|c|}
\hline \multirow{3}{*}{$\begin{array}{l}\text { Case } \\
\text { No. }\end{array}$} & \multicolumn{6}{|c|}{ F.E.V.1.0 $(\mathrm{ml} .)^{1}$} & \multirow{2}{*}{\multicolumn{2}{|c|}{$\begin{array}{c}\text { Sputum } \\
\text { Volume } \\
\text { (ml. day) }\end{array}$}} & \multirow{2}{*}{\multicolumn{2}{|c|}{$\begin{array}{c}\text { Total Times } \\
\text { Inhaler } \\
\text { Used }\end{array}$}} \\
\hline & \multirow{2}{*}{$\begin{array}{l}\text { Average } \\
\text { Active }\end{array}$} & \multirow{2}{*}{$\begin{array}{l}\text { Average } \\
\text { Placebo }\end{array}$} & \multirow{2}{*}{$\begin{array}{c}\text { Change } \\
\text { Active Placebo } \\
(\%)\end{array}$} & \multicolumn{3}{|c|}{ Reversibility $^{2}$} & & & & \\
\hline & & & & Adrenaline & Deptropine & Atropine & Active & Placebo & Active & Placebo \\
\hline$\frac{1}{2}$ & 1,042 & $\begin{array}{l}983 \\
\text { drawn }\end{array}$ & +6 & & & & 14 & 9 & 31 & 16 \\
\hline 3 & 730 & 720 & +1 & +330 & +80 & & 0.5 & 1 & 12 & 14 \\
\hline $\begin{array}{l}4 \\
5^{3}\end{array}$ & $\begin{array}{l}\text { With } \\
749\end{array}$ & ${ }_{799}$ & -7 & +220 & & & 10 & 19 & 0 & 0 \\
\hline 6 & 975 & 960 & +2 & 1220 & & & 13 & 20 & 0 & 0 \\
\hline $\begin{array}{l}7 \\
8\end{array}$ & 2,007 & $\begin{array}{r}2,725 \\
987\end{array}$ & $\begin{array}{l}-26 \\
+15\end{array}$ & & & & 3 & 2.5 & 19 & 9 \\
\hline $\begin{array}{l}8 \\
9\end{array}$ & $\begin{array}{l}1,133 \\
1,065\end{array}$ & 1,020 & $\begin{array}{r}+15 \\
+4\end{array}$ & +30 & +90 & & $\begin{array}{l}4 \\
2 \cdot 5\end{array}$ & $\begin{array}{l}1 \cdot 3 \\
2 \cdot 5\end{array}$ & 0 & 0 \\
\hline $10^{3}$ & 577 & 483 & +20 & +50 & 0 & -10 & 18.5 & 13 & 0 & 0 \\
\hline 11 & 1,282 & 1,292 & -1 & & & & 4 & $3 \cdot 5$ & 0 & 0 \\
\hline $12^{3}$ & $\begin{array}{l}886 \\
628\end{array}$ & $\begin{array}{l}938 \\
513\end{array}$ & -16 & $\begin{array}{r}+90 \\
+70\end{array}$ & $\begin{array}{r}-80 \\
+180\end{array}$ & -50 & 16 & 32 & ${ }_{0}^{0}$ & $\stackrel{0}{0}$ \\
\hline $14^{3}$ & $\begin{array}{r}628 \\
1,499\end{array}$ & $\begin{array}{r}513 \\
1,321\end{array}$ & $\begin{array}{l}+22 \\
+13\end{array}$ & +600 & $\begin{array}{l}+180 \\
+310\end{array}$ & +800 & 43 & $60 \cdot 5$ & 0 & $\begin{array}{l}0 \\
0\end{array}$ \\
\hline 15 & With & rawn & & & & & & & & \\
\hline 16 & 685 & 750 & -9 & & & & 18 & 21 & 6 & 2 \\
\hline 173 & 1,322 & 1,325 & 0 & +550 & +140 & +280 & 3 & 2 & 0 & 0 \\
\hline $18^{3}$ & 488 & 531 & -8 & +280 & +110 & $\div 90$ & 22 & 35 & 0 & 0 \\
\hline $\begin{array}{l}19 \\
2 \mathrm{C}^{3}\end{array}$ & $\begin{array}{l}683 \\
860\end{array}$ & $\begin{array}{l}635 \\
872\end{array}$ & +8 & +240 & +80 & +80 & 15 & $\begin{array}{r}20 \\
9\end{array}$ & $\begin{array}{l}3 \\
0\end{array}$ & $\begin{array}{l}1 \\
0\end{array}$ \\
\hline \multirow{2}{*}{\multicolumn{3}{|c|}{$\begin{array}{l}\text { Group average percentage } \\
\text { change active placebo }\end{array}$}} & \multirow{2}{*}{\multicolumn{2}{|c|}{+1}} & & & & & & \\
\hline & & & & & & & & Total & 71 & 42 \\
\hline
\end{tabular}

1 F.E.V. 1.0 value is average of six or seven results.

2 Reversibility = increase in F.E.V.1.0 $15 \mathrm{~min}$. after the subcutaneous injection of $0.5 \mathrm{ml} .1: 1,000$ adrenaline or $0.6 \mathrm{mg}$. atropine; or four hours after the intramuscular injection of $2 \mathrm{mg}$. deptropine.

3 In-patients.

these, three complained of dryness combined with a feeling of being 'choked up' and sore throat. Two of the latter complained of 'dryness' throughout the investigation; one was in fact worse when receiving the placebo. One patient noted a disturbance of visual accommodation.

Parenteral administration In 10 patients the relief of airways obstruction $15 \mathrm{~min}$. after $0.5 \mathrm{ml}$. $1: 1,000$ subcutaneous adrenaline was assessed. In nine, the response to deptropine, $2 \mathrm{mg}$. intramuscularly at 15 minutes and 4 hours, was also measured. The results are shown in Table III. Six patients showed an increase of over $200 \mathrm{ml}$. in F.E.V..$_{1.0}$ after the administration of adrenaline, whereas only one showed an increase of over $200 \mathrm{ml}$. after intramuscular deptropine. The average F.E.V..$_{1.0}$ results in the six patients who showed a definite response to adrenaline (indicating that at least some airways obstruction was reversible) did not show any increased advantage of active over placebo tablets when compared with the remainder of the group.

GROUP II The results from the nine patients in this group who completed the investigation are shown in Tables IV and V.

Ventilatory function The percentage improvement in F.E.V. $\cdot_{1.0}$ in the whole group when the 'active' months were compared with the 'placebo' was $23 \%$. Seven of the nine patients showed an improvement when taking the active preparation (average $33 \%$; range $6 \%$ to $66 \%$ ) and two showed deteriorations of $11 \%$ and $17 \%$. In two patients the improvement during the months of active therapy was dramatic, and five patients achieved F.E.V..$_{1.0}$ values higher than they had ever previously achieved, even in hospital.

In assessing the group results of 'placebo' and 'active' therapy, it was important to ensure that withdrawals and the date of starting treatment did not introduce a bias in the randomization of treatment due to variable climatic conditions. The period of the investigation was from $\frac{I}{0}$ November 1963 to April 1964. Apart from January, during which month six patients received $\mathcal{O}^{\circ}$ active and three placebo tablets, the monthly $N$ distribution of active and placebo treatment was very even. In the six patients who received active $\omega$ treatment in January, the average F.E.V. $\cdot_{1.0}$ value during this month was $1,084 \mathrm{ml}$. compared to the 'active' two-month average in the same patients of $1,103 \mathrm{ml}$. It seems unlikely therefore that the climate could have influenced the results significantly.

Sputum volume No difference was found in the $\stackrel{\mathbb{D}}{\circ}$ sputum volume during placebo and active treatment in this group, but none of the patients 8 
T ABLE IV

GROUP II

\begin{tabular}{|c|c|c|c|c|c|c|c|c|c|c|c|}
\hline \multirow{3}{*}{$\begin{array}{l}\text { Case } \\
\text { No. }\end{array}$} & \multicolumn{5}{|c|}{ F.E.V.1.0 $(\mathrm{ml} .)^{1}$} & \multirow{2}{*}{\multicolumn{2}{|c|}{$\begin{array}{c}\text { Sputum } \\
\text { Volume } \\
\text { (ml.) }\end{array}$}} & \multirow{2}{*}{\multicolumn{2}{|c|}{$\begin{array}{c}\text { Total Times } \\
\text { Inhaler } \\
\text { Used }\end{array}$}} & \multirow{2}{*}{\multicolumn{2}{|c|}{$\begin{array}{c}\text { Subjective } \\
\text { Score }^{3}\end{array}$}} \\
\hline & \multirow{2}{*}{$\begin{array}{l}\text { Highest } \\
\text { Pre-test }\end{array}$} & \multirow{2}{*}{$\underset{\text { Pre-test }}{\text { Immediately }}$} & \multirow{2}{*}{$\begin{array}{l}\text { Highest } \\
\text { During } \\
\text { Test }\end{array}$} & \multicolumn{2}{|c|}{ Average (4 Recordings) } & & & & & & \\
\hline & & & & Active & Placebo & Active & Placebo & Active & Placebo & Active & Placebo \\
\hline $\begin{array}{r}1 \\
2 \\
3 \\
4 \\
5 \\
6 \\
7 \\
8 \\
9 \\
10 \\
11 \\
12\end{array}$ & $\begin{array}{c}2,610 \\
1,720 \\
\text { Withdrawn } \\
\text { Withdrawn } \\
\text { Withdrawn } \\
1,310 \\
2,300 \\
950 \\
870 \\
1,210 \\
2,050 \\
1,270\end{array}$ & $\begin{array}{r}880 \\
880 \\
720 \\
750 \\
950 \\
1,470 \\
1,040\end{array}$ & $\begin{array}{r}930 \\
1,490 \\
1,100 \\
1,100 \\
1,260 \\
1,400 \\
1,500\end{array}$ & $\begin{array}{r}830 \\
1,150 \\
960 \\
1,010 \\
1,060 \\
1,350 \\
1,220\end{array}$ & $\begin{array}{r}935 \\
880 \\
770 \\
610 \\
1,000 \\
1,530 \\
760\end{array}$ & $\begin{array}{l}3 \cdot 5 \\
3 \cdot 0 \\
9 \cdot 0 \\
4 \cdot 5 \\
0 \\
6 \cdot 5 \\
0\end{array}$ & $\begin{array}{c}4.5 \\
3.0 \\
10.0 \\
4.5 \\
0 \\
6.5 \\
0\end{array}$ & $\begin{array}{r}6 \\
58 \\
1 \\
84 \\
72 \\
393 \\
0\end{array}$ & $\begin{array}{r}10 \\
102 \\
14 \\
419 \\
68 \\
460 \\
0\end{array}$ & $\begin{array}{l}23 \\
18 \\
24 \\
22 \\
19 \\
12 \\
24\end{array}$ & $\begin{array}{r}18 \\
15 \\
24 \\
9 \\
17 \\
16 \\
24\end{array}$ \\
\hline
\end{tabular}

${ }_{1}$ F.E.V.1.0 assessment always carried out at the same time and in the same relation to regime of prednisolone therapy.

2 Volume expectorated between waking and 9 a.m.

3 Weekly patient assessment: 3 , good; 2 , indifferent ; 1 , bad.

TAB LE V

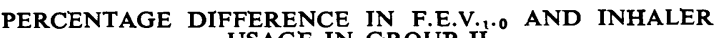
USAGE IN GROUP II

\begin{tabular}{|c|c|c|}
\hline $\begin{array}{l}\text { Case } \\
\text { No. }\end{array}$ & $\underset{(\%)^{1}}{\text { Change in F.E.V.1.0 }}$ & $\begin{array}{l}\text { Reduction in Times } \\
\text { Inhaler Used }(\%)^{1}\end{array}$ \\
\hline $\begin{array}{r}1 \\
2 \\
6 \\
7 \\
8 \\
9 \\
10 \\
11 \\
12\end{array}$ & $\begin{array}{r}+17 \\
+26 \\
-11 \\
+31 \\
+25 \\
+66 \\
+6 \\
-17 \\
+61\end{array}$ & $\begin{array}{r}74 \\
60 \\
40 \\
43 \\
93 \\
80 \\
0 \\
15 \\
\end{array}$ \\
\hline Group aver & rence +23 & Average 51 \\
\hline
\end{tabular}

1 Placebo values are used as standard.

produced more than $10 \mathrm{ml}$. sputum during the short period of each day in which the sputum was collected.

Inhaler usage Eight of the nine patients regularly used an inhaler, and inhaler usage was $49 \%$ less during the period of active than during the period of placebo administration.

Subjective preference The weekly score for good (3), indifferent (2), and bad (1) averaged 21/24 for the two 'active' months and 18/24 for the two 'placebo' months.

Side-effects One patient was withdrawn from the investigation because of disturbances in visual accommodation. One patient had to be withdrawn during a time when she was in. fact receiving placebo tablets, because she felt they were doing her harm. She also complained of marked dryness of the mouth, worse when she had been taking the active than the placebo tablets, although still pronounced with the latter. Only three of the nine patients who completed the investigation complained of dry mouth, and this was comparatively mild. No other side-effects were encountered.

\section{DISCUSSION}

The number of patients studied is not sufficiently large to draw valid statistical conclusions from the results. However we agree with $\mathrm{McNicol}$ and Bruyns (1964) that it is unlikely that deptropine has an important place in the treatment of bronchitis, although the results of an investigation of long-term administration are awaited. The hope that a decrease in sputum volume, if achieved, in bronchitic patients with excessive sputum production would be of benefit to them was not substantiated. Although the sputum volume was reduced in some patients who expectorated a large volume, this did not result in symptomatic improvement, certainly within the comparatively short period of this investigation. Further experience outside this investigation suggests that the drug, by drying the secretions and so making the sputum tenacious and difficult to expectorate, may lead to retention of sputum and even lobar collapse. On the other hand, two patients with copious frothy sputum associated with asthma, also outside the investigation, have obtained good symptomatic relief from deptropine.

The results within the investigation also proved disappointing in the non-corticosteroid-treated 'asthmatic' group. Indeed, one of the out-patients withdrawn was admitted to hospital because increasingly severe asthma developed during the week of active deptropine therapy. It must again be emphasized, however, that the number 
investigated was very small and there may be a few patients with chronic comparatively mild asthma who derive worthwhile benefit.

It is always possible that inconclusive results of 'group investigation' may mask a good therapeutic response in a few individuals within the group. This is particularly so when a drug is being assessed with side-effects which may adversely affect the recorded parameters of response. There were no patients in group I who could be considered to have gained clear-cut benefit. However, the majority of the patients in group II (those receiving corticosteroid treatment) showed a significant response. Perhaps more important, the F.E.V. ${ }_{1.0}$ in three patients rose during the 'active' months to values higher than any previously recorded, and in two patients they increased to $60 \%$ above the average F.E.V $\cdot_{1.0}$ estimations in the 'placebo' months. Treatment with deptropine has been continued in five patients because of maintained objective evidence of improvement. Incidentally, all these patients have subsequently expressed a desire to continue with the drug.

In view of the promising results in this group, a more extensive investigation, which will provide statistical data, is in progress. Even if statistical confirmation of these results is obtained, however, it will still remain to be shown that deptropine with its atropine-like action does not adversely affect regional pulmonary ventilation/perfusion relations. This is not as unlikely as it may at first sight appear, for the work of Daly, Ross, and Behnke (1963) suggests that atropine, in addition to other effects on the cardiovascular system, reduces pulmonary blood volume.

It seems probable that a decrease in airways obstruction associated with deptropine therapy is largely due to its cholinolytic properties. There is, however, no evidence yet, in a limited number of patients investigated, that the response to oral deptropine can be predicted from the effect on forced expiration of the parenteral administration of either atropine or, indeed, deptropine itself.

Side-effects during treatment with deptropine are common, and dry mouth, difficulty in coughing, failure of visual accommodation, urinary retention, psychic upsets, drowsiness, nausea, and light-headedness have been reported as occurring in between 10 and $60 \%$ of patients (Quarles van Ufford and Bruens, 1962; General Practitioner Clinical Trials, 1964 ; Schmidt, 1962 ; McNicol and Bruyns, 1964). Thirty-five per cent. of the patients in this investigation complained of dry mouth and $7 \%$ complained of disturbances of vision. Experience outside this investigation has indicated that the dry mouth will disappear within a few days if the deptropine is withdrawn and will not necessarily recur when treatment is recommenced. It is rarely troublesome when the dose is $1 \mathrm{mg}$. or less daily, but a dose of $2 \mathrm{mg}$. per day may produce such uncomfortable dryness of the mouth that treatment has to be stopped altogether. However, only one out of 12 patients receiving long-term deptropine had to be withdrawn because of the side-effects of the drug. Neither drowsiness nor depression of any significant degree was found during this investigation. A history suggestive of prostatism or glaucoma should be regarded as a definite contra-indication to deptropine therapy.

SUMMARY

None of 11 patients suffering from bronchitis, or of six suffering from asthma, was found to respond within one week by a significant increase in F.E.V..$_{1.0}$ to deptropine by mouth, and no significant difference in F.E.V..$_{1.0}$ response to active and placebo therapy was noted during that time. The sputum volume is usually reduced in patients with a large volume of sputum, but this does not appear necessarily to benefit ventilatory function. The long-term effect of deptropine alone on bronchitis or asthma was not assessed.

Deptropine does appear to have a place in the treatment of some patients who have responded only partially to corticosteroid therapy. When given in conjunction with prednisolone, there was a dramatic rise in F.E.V. $\cdot_{1.0}$ in two out of nine patients and a moderate improvement in a further three. There was a significant reduction in inhaler usage in this group. Administered by intramuscular injection, deptropine is slow-acting and has a prolonged effect with a maximum relief of airways obstruction usually occurring between two and four hours after injection. It rarely produces as great a maximum rise in F.E.V $\cdot_{1.0}$ as subcutaneous adrenaline.

Side-effects during treatment with deptropine are common ; $35 \%$ of the patients in this investigation complained of dry mouth and $7 \%$ complained of disturbance of visual accommodation.

We are indebted to Brocades (Great Britain) Ltd. for supplies of Brontina and placebo tablets, and to Dr. John Rae for his help in planning the investigation. Technical assistance was provided by Miss S. Merchant, Miss A. G. Gregor, Miss S. Robertson, Staff-Nurse G. Mackenzie, and Sister E. Simpson. Our thanks are also due to Miss J. Holywell for her help with the preparation of the manuscript. 


\section{REFERENCES}

Booy-Noord, H., Orie, N. G. M., ten Cate, H. J., Sloots, S., and Bolt, D. (1957). The influence of various drugs on the vital capacity of asthmatics. Int. Arch. Allergy, 10, 321.

Daly, W. J., Ross, J. C., and Behnke, R. N. (1963). The effect of changes in the pulmonary vascular bed produced by atropine, pulmonary engorgement, and positive-pressure breathing on diffusing and mechanical properties of the lunz. J. clin. Invest., diffusing

Funcke, A. B. H., de Jonge, M. C., Tersteege, H. M., Mulder, D. Harms, A. F., and Nauta, W. Th. (1962). Pharmacological properties of 3-(10,11-dihydro-5H-dibenzo[a,d],cyclo-hepten-5yloxy)-tropane (BS 6987, dibenzheptropine citrate). Acta physiol. pharmacol. neerl., 11, 104.

General Practitioner Clinical Trials (1964). Practitioner, 192, 682. Reports Nos. 57 and 58 of the General Practitioner Research Group.
McNicol, M. W., and Bruyns, C. (1964). Dibenzheptropine citrate ("Brontina")-a double blind trial in chronic chest disease. Brit. J. Dis. Chest, 58, 135.

Quarles van Ufford, W. J., and Bruens, J. C. E. (1962). Meded. Sticht. exp. Onderz. Allerg., no. 7

Scherrer, M. (1962), Ibid., no. 7.

Schmidt, F. (1962). The frequency and diagnosis of chronic asthmatic bronchitis and some clinical experiences with a new synthetic bronchospasmolytic drug. Lecture given at the Antwerp Therapeutic Congress.

Stelt, C. van der, Harms, A. F., and Nauta, W. Th. (1961). The effect of alkyl-substitution in drugs. -V. Synthesis and chemical properties of some dibenzo[a,d]1,4-cycloheptadienyl ethers. $J$. med. pharm. Chem., 4, 335.

Van Geuns, H. A., and Scherrer, M. (1955). Einige Erfahrungen mit "Thiazinamium" bei Asthma bronchiale. Int. Arch. Allergy, 7, 111.

Voorhorst, R. (1962). Drug therapy of vasomotor rhinitis and asthma: dibenzheptropine, a valuable adjuvant in the corticoid treatment. Curr. the $:$ R2s., 4,31 . 